\title{
The Use of Learning Model Picture and Picture to Improve Understading Concept of Science
}

\section{Lili Maryatul Muarofah}

SD Mintaragen 3 Kota Tegal

lilimm5151@gmail.com

\section{Article History}

accepted 01/11/2020

approved 08/11/2020

published 15/11/2020

\begin{abstract}
Purpose of the research is to improve understanding concept of science of $5^{\text {th }}$ grade students of SD Negeri Mintaragen 3 of Kecamatan Tegal Timur,Tegal of 2020/2021 academic year by using picture and picture. This research is classroom action research. The research uses collaboration between author and teacher of class V. Data is collected by using documentation, observation and test techniques. The research consists of 2 cycles and every cycle comprises four stages, namely: (1) action planning, (2) action implementation, (3) observation and (4) reflection. The research found that average grade before action (precycle) was 62.08 with classical completeness was $12.5 \%$. At cycle I, classroom average grade achieved 70.41 and classical completeness was $50 \%$. At cycle II, the average grade increased to 80.41 with classical completeness was $87.5 \%$, it can be concluded that the use of Picture and Picture can improve understanding concept of science.
\end{abstract}

Keywords : understanding concept, science, picture and picture

\begin{abstract}
Abstrak
Tujuan penelitian ini adalah untuk meningkatkan Pemahaman konsep pembelajaran IPA pada siswa kelas V SD Negeri Mintaragen 3 Kecamatan Tegal Timur Kota Tegal tahun pelajaran 2020/2021 melalui model pembelajaran Picture and Picture. Penelitian ini berbentuk Penelitian Tindakan Kelas. Penelitian ini berupa kolaborasi atau kerjasama antara peneliti dengan guru kelas $\mathrm{V}$. Teknik pengumpulan data yang digunakan adalah dokumentasi, observasi dan tes. Penelitian ini terdiri dari 2 siklus, setiap siklus terdiri dari empat tahap, yaitu: (1) perencanaan tindakan, (2) pelaksanaan tindakan, (3) observasi dan (4) refleksi. Berdasarkan hasil penelitian, diperoleh nilai rata-rata sebelum tindakan (pra siklus) yaitu 62,08 dengan ketuntasan klasikal 12,5\%. Pada siklus I nilai rata-rata kelas mencapai 70,41 dengan ketuntasan klasikal 50\%. Pada siklus II nilai rata-rata kelas meningkat 80,41 dengan ketuntasan klasikal 87,5\%. Dengan demikian dapat disimpulkan bahwa melalui model pembelajaran Picture and Picture, pemahaman konsep pembelajaran IPA dapat meningkat.
\end{abstract}

Kata Kunci: Pemahaman konsep, IPA, Picture and Picture

Social, Humanities, and Education Studies (SHEs): Conference Series https://jurnal.uns.ac.id/shes

p-ISSN 2620-9284

e-ISSN 2620-9292 


\section{PENDAHULUAN}

Pembelajaran di Sekolah Dasar mengacu pada kurikulum 2013 menggunakan pembelajaran tematik. Mata pelajaran IPA berhubungan dengan cara mencari tahu tentang alam secara sistematis, sehingga IPA bukan hanya penguasaan kumpulan sistematis dan bukan hanya penguasaan kumpulan pengetahuan yang berupa faktafakta, konsep-konsep atau prinsip-prinsip saja, tetapi juga merupakan suatu proses penemuan (Sri Sulistyorini, 2007: 39).

Kerena adanya wabah Covid 19, maka pembelajaran yang biasanya dilaksanakan secara tatap muka langsung diubah menjadi pembelajaran daring. Dalam pembelajaran daring ini, antara peserta didik dan guru tidak terjadi tatap muka secara langsung. Selama pembelajaran daring ini guru hanya memberikan tugas yang diberikan lewat Whatsapp Grup. Dimana dalam WAG guru hanya memberikan tugas saja dan peserta didik mengerjakan tugas dan materi yang ada di buku siswa atau pun yang terdapat di LKPD. Sehingga pembelajaran yang terjadi monoton dan membosankan. Oleh karena itu diperlukan model pembelajaran yang mampu menarik perhatian peserta didik namun tidak membosankan dan juga bermakna, sehingga materi dapat terserap dengan baik. Salah satu metode pembelajaran yang dapat digunakan yaitu Picture and Picture.

Penelitian peningkatan pemahaman konsep pembelajaran IPA dengan menggunakan Model Pembelajaran Picture and Picture pada siswa kelas V SD Negeri Mintaragen 3 Kecamatan Tegal Timur Kota Tegal ini tidak terlepas atau mengacu dari penelitian sebelumnya. Diantara penelitian yang relefan yaitu Weni Widiawati (2017) dengan judul penelitian penerapan model picture and picture untuk meningkatkan hasil belajar siswa pada subtema kekayaan sumber energi di indonesia (Penelitian Tindakan kelas dilaksanakan Di Kelas IV SDN Cicalengka 05 Kecamatan Cicalengka Kabupaten Bandung), Nurdiana Ida (2017) dengan judul penelitian Penerapan model pembelajaran kooperatif tipe picture and picture untuk meningkatkan hasil belajar IPAsiswa kelas II MI Bendiljati Wetan Tulungagung.

Berdasarkan identifikasi masalah yang ada, maka rumusan masalah dalam penelitian ini adalah "Apakah penggunaan model pembelajaran Picture and Picture dapat meningkatkan pemahaman konsep pembelajaran IPA tentang Hubungan Komponen Ekosistem dan Jaring-jaring Makanan pada siswa kelas V SD Mintaragen 3 Kecamatan Tegal Timur Kota Tegal?". Tujuan penelitian ini yaitu untuk meningkatkan pemahaman konsep pembelajaran IPA tentang Hubungan Komponen Ekosistem dan Jaring-jaring Makanan pada Tema 5 Sub tema 1 kelas $V$ di SD Mintaragen 3 Kecamatan Tegal Timur Kota Tegal tahun Ajaran 2020/2021

\section{METODE}

Penelitian yang dilakukan berbentuk penelitian tindakan kelas. Penelitian Tindakan Kelas ini akan dilaksanakan pada tahun ajaran 2020/2021 Semester 1 sedangkan Tempat pelaksanaan yaitu Kelas V SD Mintaragen 3 Kota Tegal. Subjek penellitian ini adalah guru dan peserta didik kelas $V$ sebanyak 24 anak yang terdiri atas 14 siswa laki-laki dan 10 siswa perempuan. Penelitian ini menggunakan tiga teknik pengumpulan data yang terdiri dari; 1) dokumentasi; 2) observasi; 3) tes.

Sumber data yang akan dimanfaatkan dalam penelitian ini adalah Informasi data yang diperoleh dari narasumber yang terdiri dari siswa kelas V SD Negeri Mintaragen 3 Kecamatan Tegal Timur Kota Tegal yang berjumlah 24 siswa dan guru kelas V, Arsip dan Dokumen, data nilai hasil pembelajaran IPA yang digunakan sebagai data nilai awal siswa sebelum dilakukan tindakan dan hasil observasi pemahaman konsep pembelajaran IPA.

Semua data yang dikumpulkan hendaknya mencerminkan apa yang sebenarnya diukur atau diteliti. Untuk memperoleh data yang valid dalam penelitian ini, peneliti menggunakan teknik triangulasi. Triangulasi merupakan teknik yang didasari pola pikir 
fenomenologi yang bersifat multiperspektif. Artinya untuk menarik simpulan yang mantap dan bisa diterima kebenarannya, peneliti perlu mengkajinya dari berbagai sudut pandang (Sutopo, H. B., 2002). Supaya hasil penelitian dapat terwujud sesuai dengan tujuan yang diharapkan maka dalam menganalisis data penelitian ini menggunakan analisis model interaktif Milles dan Huberman. Kegiatan pokok analisa model ini meliputi : reduksi data, penyajian data, kesimpulan-kesimpulan penarikan / verifikasi (Milles dan Huberman, 2007: 20).

\section{HASIL DAN PEMBAHASAN}

Data nilai yang digunakan dalam penelitian ini yaitu penilaian pengetahuan dan penelitian keterampilan. Dari daftar nilai yang terdapat pada lampiran dapat diketahui bahwa nilai hasil penilaian keterampilan dan pengetahuan pada pemahaman konsep IPA pada kondisi awal sebelum tindakan yaitu siswa yang mendapat nilai < 65 (KKM) pada penilaian keterampilan ada 21 siswa atau 87,5\% dan siswa yang mendapat nilai $>65$ (KKM) sebanyak 3 siswa atau $12,5 \%$. Serta nilai rata-ratanya adalah 62,08. Dan pada penilaian pengetahuan ada 19 siswa yang mendapat nilai < 65 (KKM) atau $79,17 \%$ dan siswa yang mendapat nilai > 65 (KKM) sebanyak 5 siswa atau 20,83\%. Serta nilai rata-ratanya adalah 62,58 .

Dapat diketahui bahwa nilai hasil penilaian keterampilan dan pengetahuan pada pemahaman konsep IPA pada siklus 1 yaitu siswa yang mendapat nilai $<65$ (KKM) pada penilaian keterampilan ada 13 siswa atau 54,2\% dan siswa yang mendapat nilai $>65$ (KKM) sebanyak 11 siswa atau 45,8 \%. Serta nilai rata-ratanya adalah 68,2. Dan pada penilaian pengetahuan ada 12 siswa yang mendapat nilai $<65$ (KKM) atau 50\% dan siswa yang mendapat nilai > 65 (KKM) sebanyak 12 siswa atau 50\%. Serta nilai rata-ratanya adalah 70,41

Dapat diketahui bahwa nilai hasil penilaian keterampilan dan pengetahuan pada pemahaman konsep IPA pada siklus 2 yaitu siswa yang mendapat nilai < 65 (KKM) pada penilaian keterampilan ada 4 siswa atau 16,7 \% dan siswa yang mendapat nilai > 65 (KKM) sebanyak 20 siswa atau 83,3\%. Serta nilai rata-ratanya adalah 78,41. Dan pada penilaian pengetahuan ada 3 siswa yang mendapat nilai $<65(\mathrm{KKM})$ atau $12,5 \%$ dan siswa yang mendapat nilai > 65 (KKM) sebanyak 21 siswa atau 87,5\%. Serta nilai rata-ratanya adalah 80,41 . Berdasarkan hasil penelitian yang telah dilaksanakan mulai dari prasiklus, siklus I dan siklus II, dapat digambarkan dalam tebel seperti gambar berikut:

\begin{tabular}{lcc}
\hline Data nilai & $\begin{array}{c}\text { Skor rata-rata } \\
\text { pengetahuan }\end{array}$ & $\begin{array}{c}\text { Skor rata-rata } \\
\text { keterampilan }\end{array}$ \\
\hline Prasikus & 62,08 & 62,58 \\
Siklus I & 70,41 & 68,20 \\
Siklus II & 80,41 & 78,41 \\
\hline
\end{tabular}

\section{Tabel 1. Data Nilai rata-rata skor pengetahuan dan keterampilan}

Berdasarkan tabel 1. Rata-rata skor pengetahuan dari awal prasiklus yaitu 62,08 dan rata-rata skor keteampilan 62,58 dimana ada 21 siswa yang masih dibawah KKM dan 3 siswa yang sudah melampaui KKM. Sedangkan untuk skor pengetahuan dari siklus 1 70,41 dan skor rata-rata keterampilan 68,20 dimana ada 15 siswa yang masih dibawah KKM dan 9 siswa yang melampaui KKM. Dan untuk siklus II skor ratarata pengetahuan yaitu 80,41 dan skor rata-rata keterampilan 78,41 dimana ada 4 orang yang masih dibawah KKM dan 20 siswa yang sudah melampaui KKM.

Berdasarkan tabel 1 diatas dapat dibuatkan diagram sebagai berikut: 


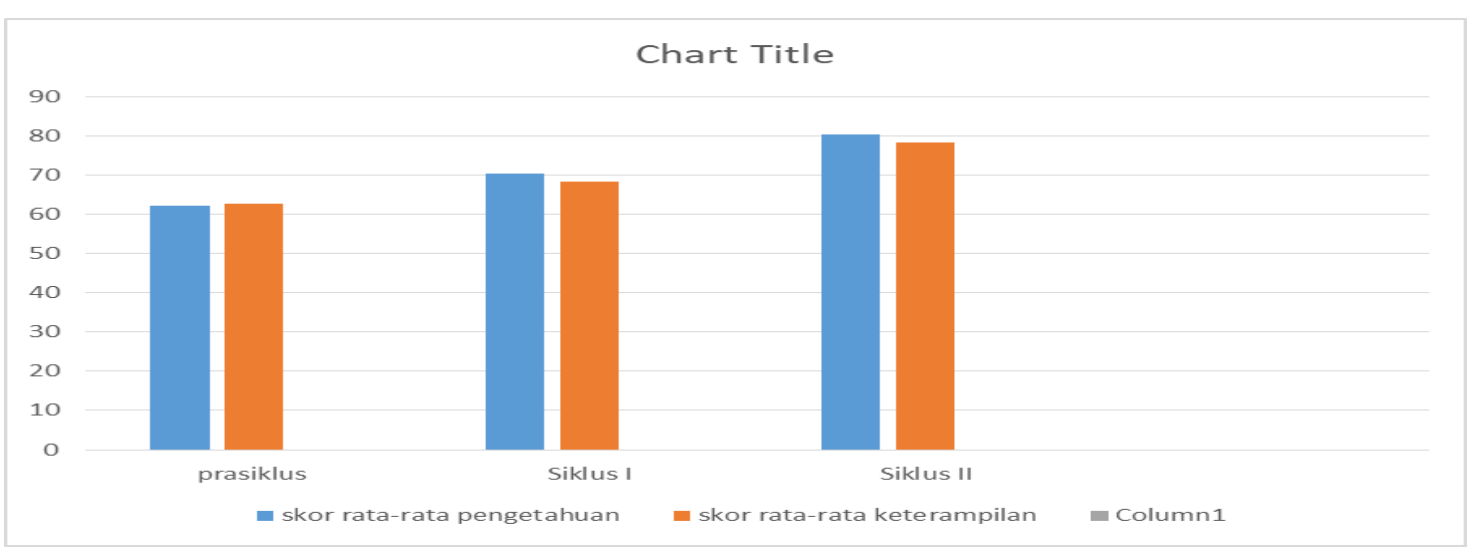

\section{Gambar 1. Skor rata-rata penilaian pengetahuan dan keterampilan}

Dengan melihat hasil penelitian di atas dapat diketahui adanya peningkatan proses pemahaman konsep pembelajaran IPA terutama setelah Model Picture and Picture. Peningkatan terlihat dari perhitungan nilai rata-rata hasil penilaian keterampilan dan pengetahuan yang diperoleh siswa pada kondisi awal sebelum dilaksanakan tindakan dan setelah dilaksanakan tindakan siklus I dan siklus II.

\section{SIMPULAN}

Berdasarkan hasil penelitian tindakan kelas yang dilaksanakan dalam dua siklus tersebut, maka dapat ditarik simpulan bahwa pembelajaran dengan menggunakan model pembelajaran picture and picture dapat meningkatkan pemahaman konsep pembelajaran IPA pada siswa kelas V SD Negeri Mintaragen 3. Peningkatan pemahaman konsep pembelajaran IPA tersebut dapat dibuktikan dengan meningkatnya penilaian keterampilan dan penilaian pengetahuan pada setiap siklusnya yaitu: Pra siklus nilai rata-rata penilaian keterampilan siswa 62,58 dan penilaian pengetahuan siswa 62,08 , siklus I nilai rata-rata penilaian keterampilan siswa 68,2 dan penilaian pengetahuan siswa 70,41 dan siklus II nilai rata-rata penilaian keterampilan siswa 78,41 dan penilaian pengetahuan siswa 80,41 . Tingkat ketuntasan belajar siswa pada kondisi awal sebanyak 3 siswa atau 112,5\%, 12 siswa atau $50 \%$ pada siklus I dan 21 siswa atau 87,5\% pada siklus II. Dengan demikian, melalui model pembelajaran picture and picture pemahaman konsep pembelajaran siswa dapat meningkat.

Berkaitan dengan hasil penelitian ini maka dapat dikemukakan implikasi hasil penelitian sebagai berikut: Implikasi teoritis dari penelitian ini adalah bahwa ada peningkatan pemahaman konsep pembelajaran IPA. Penelitian tersebut juga dapat dipertimbangkan untuk menggunakan model pembelajaran picture and picture pada pembelajaran bagi guru dalam memberikan materi pelajaran siswa. Implikasi praktis Hasil penelitian ini dapat digunakan sebagai masukan bagi guru dan calon guru untuk meningkatkan keefektifan strategi guru dalam mengajar dan meningkatkan kualitas proses belajar-mengajar yang berhubungan dengan pemahaman konsep pembelajaran. 
SHEs: Conference Series 3 (3) (2020) $57-61$

DAFTAR PUSTAKA

Adhi, Ginajar.(2017). Model Pembelajaran Picture and Picture. Diakses dari https://www.tripven.com/pembelajaran-picture-and-picture/

Hamdayama (2016, hlm. 132-182). Model-model Pembelajaran. Diakses dari https://serupa.id/model-pembelajaran-pengertian-ciri-jenis-macam-contoh/

Iskandar (2001:2). Hakikat pembelajaran IPA di Sekolah Dasar. Diakses dari https://silabus.org/hakikat-pembelajaran-ipa-di-sd/

Nurdiana, Ida. (2013). UPT Universita Negeri Malang. Diakses dari http://library.um.ac.id/ptk/index.php?mod=detail\&id=59458

Oemar Hamalik, (2008: 25). Hakikat dan Tujuan Pembelajaran IPA. Diakses dari https://lestarysnote.blogspot.com/2016/03/hakikat-dan-tujuan-pembelajaran-ipa.html

Supardi (2006). Pengertian PTK, Tujuan, Karakteristik, Prinsip, Langkah dan Model Penelitian Tindakan Kelas (PTK) Lengkap. Diakses dari https://www.pelajaran.co.id/2019/15/pengertian-ptk-tujuan-karakteristik-prinsiplangkah-dan-model-penelitian-tindakan-kelas-ptk.html

Suprihatiningrum (2013, hlm. 145). Pengertian Model Pembelajaran. Di akses dari https://serupa.id/model-pembelajaran-pengertian-ciri-jenis-macam-contoh/

Widiawati, Weni (2017).UPT Perpustakaan Universitas Pasundan. Diakses dari http://repository.unpas.ac.id/30771/ 